\title{
Influence of the statin therapy on cardiovascular remodeling in arterial hypertension, combined with subclinical hypothyroidism
}

\author{
Ye. V. Novikov ${ }^{\star A, B, C, D}$, M. S. Potapenko ${ }^{\mathrm{C}, \mathrm{D}, \mathrm{E}, \mathrm{F}}$
}

Zaporizhzhia State Medical University, Ukraine

A - research concept and design; B - collection and/or assembly of data; C - data analysis and interpretation; D - writing the article; $\mathrm{E}$ - critical revision of the article; $\mathrm{F}$ - final approval of the article

There is a proven relation between hypothyroidism and appearance of the pronounced structural and functional changes of the heart and blood vessels as well as atherosclerosis and its related diseases progress. At the same time, there is a lack of information regarding the influence of statins on indices of the structure and function of the heart and blood vessels in patients with arterial hypertension $(\mathrm{AH})$ combined with subclinical hypothyroidism $(\mathrm{SH})$.

Aim. To study the effect of the long-term statin therapy on the cardiac structure and function, as well as on vascular remodeling in patients with arterial hypertension combined with subclinical hypothyroidism.

Material and methods. The study involved 31 patients with arterial hypertension grade $1-3$, stage II, of high and very high additional cardiovascular risk, with a concomitant SH. All patients received a combination of two or three first-line antihypertensive drugs at average therapeutic daily doses and atorvastatin at a dose of 20-30 mg per day. Prior to treatment and after one year of follow-up, all patients underwent an echocardiographic examination and a carotid artery scan on My Lab Seven (Italy) device as well as a 24h-blood pressure monitoring on a bifunctional device "Cardiotechnics-04" (Inkart, St. Petersburg, $\mathrm{RF}$ ) with the simultaneous registration of BP and ECG.

Results. Under the influence of therapy, the target level of systolic blood pressure was reached in $74 \%$ (23/31) of patients during the daytime observation period, in $65 \%$ (20/31) of patients during the nighttime observation period; target diastolic blood pressure for the daytime observation period - in $87 \%$ (27/31) of patients, for the nighttime observation period - in $71 \%$ $(22 / 31)$ patients. However, there was no significant change in the size of cavities of the left atrium and both ventricles, ejection fraction (before treatment $68.84 \pm 5.43 \%$, after $67.13 \pm 5.45 \%$ ), thickness of the interventricular septum and posterior wall, relative wall thickness (before treatment $0.41 \pm 0.07$, after $0.41 \pm 0.07, P=0.871$ ), LV mass index (before treatment $122.29 \pm 37.36 \mathrm{~g} / \mathrm{m}^{2}$, after $118.00 \pm 31.00 \mathrm{~g} / \mathrm{m}^{2}, P=0.849$ ), indices of diastolic function of the left ventricle (LV). The specific gravity of patients with eccentric LV hypertrophy after a year of treatment increased from $32 \%$ to $39 \%$ ( $P=0.5668)$, with concentric hypertrophy decreased from $42 \%$ to $39 \%(P=0.8107)$, with normal LV geometry - from $19 \%$ to $16 \%$ $(\mathrm{P}=0.7570)$. The number of patients with $\mathrm{AH}$ with a concomitant SH with signs of a concentric LV remodeling remained unchanged - before treatment $6 \%$, after $6 \%$. The influence of the statin therapy on vascular remodeling in patients with $\mathrm{AH}$ with a concomitant $\mathrm{SH}$ was characterized by a tendency towards a decrease in the thickness of the intima-media complex of the right $(0.769 \pm 0.276 \mathrm{~mm}$ vs. $0.701 \pm 0.222 \mathrm{~mm}, \mathrm{P}=0.512)$ and left $(0.759 \pm 0.185 \mathrm{~mm}$ vs. $0.745 \pm 0.179 \mathrm{~mm}$, $\mathrm{P}=0.988)$ common carotid arteries.

Conclusion. In patients with $\mathrm{AH}$ with a concomitant $\mathrm{SH}$, the antihypertensive therapy during the year with the first-line drugs with addition of statins was associated with achievement of the target SBP level in the active period in $74 \%$, in the passive period - in $65 \%$ of patients (according to the $24 \mathrm{~h}-\mathrm{BPM}$ data), but was not accompanied by a significant decrease in the cavity size, wall thicknesses, LV mass, improvement of LV diastolic filling, reduction in thickness of the intima-media complex.

\section{Вплив статинотерапії на серцево-судинне ремоделювання при артеріальній гіпертензії, що поєднана з субкиінічним гіпотиреозом}

\section{€. В. Новіков, М. С. Потапенко}

Доведено зв'язок гіпотиреозу з появою виражених структурно-фуннцціональних змін серця та судин, прогресуванням атеросклерозу та хвороб, що з ним пов'язані. Однак бракує інформації щодо впливу статинів на показники структури та функції серця та судин у хворих на гіпертонічну хворобу (ГХ), що поєднана з субклінічним гіпотиреозом (СГ).

Мета роботи - вивчити вплив тривалої статинотерапії на показники структури та функції серця та судинне ремоделювання у хворих на гіпертонічну хворобу, що поєднана з субклінічним гіпотиреозом.

Матеріали та методи. У дослідження залучили 31 особу, яка хвора на ГX 1-3 ступеня, II стадії, високого та дуже високого додаткового кардіоваскулярного ризику з супутнім СГ. Усі пацієнти отримували комбінацію 2-3 антигіпертензивних препаратів першої лінії в середніх терапевтичних добових дозах та аторвастатин у дозі 20-30 мг на добу. До початку лікування та через рік спостереження всім хворим виконали ехокардіографічне дослідження та сканування сонних артерій на пристрої My Lab Seven (Італія) та добове моніторування артеріального тиску на біфункціональному пристрої «Кардиотехника-04» («Инкарт», СПб, РФ) з одночасною реєстрацією артеріального тиску й електрокардіограми.
Key words:

arterial

hypertension, subclinical hypothyroidism, cardiovascular remodeling, statins.

Pathologia 2020; 17 (3), 319-324

*E-mail: doctornovikov@ukr.net

Киючові слова: гіпертонічна хвороба, субклінічний гіпотиреоз, серцево-судинне ремоделювання статини.

Патологія. 2020

T. 17, № 3(50). c. 319-324 сягли 74 \% (23/31) хворих, за нічний період спостереження - 65 \% (20/31); цільового рівня діастолічного артеріального 
тиску за денний період спостереження - 87 \% (27/31) пацієнтів, за нічний період спостереження - 71 \% (22/31). Але не зареєстрували вірогідну зміну розмірів порожнин лівого передсердя та обох шлуночків, фракції викиду (до лікування $68,84 \pm 5,43 \%$, після - 67,13 $\pm 5,45 \%$ ), товщини міжшлуночкової перетинки та задньої стінки, відносної товщини стінки (до лікування $-0,41 \pm 0,07$, після 0,41 $\pm 0,07, p=0,871$ ), індексу маси міокарда (до лікування $-122,29 \pm 37,36$

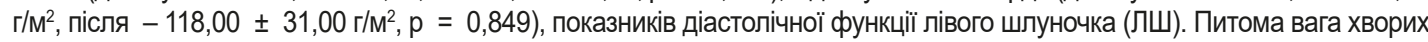
з ексцентричною гіпертрофією ЛШ через рік лікування збільшилася з 32 \% до $39 \%$ ( $p=0,5668)$, із концентричною гіпертрофрією зменшилася з $42 \%$ до $39 \%$ ( Кількість Хворих на ГХ із супутнім СГ з ознаками концентричного ремоделювання ЛШ залишилась незмінною: до лікування $-6 \%$, після $-6 \%$. Вплив статинотерапії на судинне ремоделювання у хворих на ГХ із СГ характеризувався тенденцією до зменшення товщини інтима-медіального комплексу правої $(0,769 \pm 0,276$ мм проти 0,701 $\pm 0,222$ мм, $p=0,512)$ та лівої $(0,759 \pm 0,185$ мм проти 0,745 $\pm 0,179$ мм, $p=0,978)$ загальних сонних артерій.

Висновки. У хворих на ГХ із супутнім СГ антигіпертензивна терапія протягом року препаратами першої лінії з додаванням статинів асоціюється з досягненням цільового рівня САТ в активний період доби у 74 \%, в пасивний період -y $65 \%$ пацієнтів (за даними ДМАТ), але не супроводжувалася вірогідним зменшенням порожнин, товщини стінок, маси міокарда ЛШ, поліпшенням його діастолічного наповнення, зменшенням товщини інтима-медіального комплексу.

Ключевые слова: гипертоническая болезнь, субклинический гипотиреоз, сердечнососуаистое ремоделирование, статины.

Патология. 2020 T. 17, № 3(50).

C. 319-324

\section{Влияние статинотерапии на сердечно-сосудистое ремоделирование при артериальной гипертензии, сочетанной с субклиническим гипотиреозом}

\section{Е. В. Новиков, М. С. Потапенко}

Доказана связь гипотиреоза с появлением выраженных структурно-функциональных изменений сердца и сосудов, прогрессированием атеросклероза и связанных с ним болезней. В то же время, недостаточно информации о влиянии статинов на показатели структуры и фуннции сердца и сосудов у больных гипертонической болезнью (ГБ), сочетанной с субклиническим гипотиреозом (СГ).

Цель работы - изучить влияние длительной статинотерапии на показатели структуры и функции сердца и сосудистое ремоделирование у больных гипертонической болезнью, сочетанной с субклиническим гипотиреозом.

Материалы и методы. В исследование включены 31 больной ГБ 1-3 степени, II стадии, высокого и очень высокого дополнительного кардиоваскулярного риска с сопутствующим СГ. Все пациенты получали комбинацию 2-3 антигипертензивных препаратов первой линии в средних терапевтических суточных дозах и аторвастатин в дозе 20-30 мг в сутки. До начала лечения и через год наблюдения всем больным выполнено эхокардиографическое исследование и сканирование сонных артерий на устройстве My Lab Seven (Италия) и суточное мониторирование артериального давления на бифункциональном приборе «Кардиотехника-04» («Инкарт», СПб, РФ) с одновременной регистрацией артериального давления и электрокардиограммы.

Результаты. Под влиянием терапии целевого уровня систолического артериального давления в дневной период наблюдения достигли 74 \% (23/31) больных, за ночной период наблюдения - 65 \% (20/31); целевого уровня диастолического артериального давления в дневной период наблюдения - 87 \% (27/31) пациентов, за ночной период наблюдения - 71 \% (22/31). Однако не зарегистрировали достоверное изменение размеров полостей левого предсердия и обоих желудочков, фракции выброса (до лечения $-68,84 \pm 5,43 \%$, после $-67,13 \pm 5,45 \%$ ), толщины межжелудочковой перегородки и задней стенки, относительной толщины стенки (до лечения $-0,41 \pm 0,07$, после $0,41 \pm 0,07, p=0,871$ ), индекса массы миокарда (до лечения $-122,29 \pm 37,36 \mathrm{r} / \mathrm{M}^{2}$, после $-118,00 \pm 31,00 \mathrm{r} / \mathrm{m}^{2}$, $\mathrm{p}=0,849)$, показателей диастолической функции левого желудочка (ЛЖ). Удельный вес больных с эксцентричной гипертрофией ЛЖ через год лечения увеличился с $32 \%$ до $39 \%$ (р = 0,5668), с концентрической гипертрофией уменьшился с $42 \%$ до $39 \%$ ( $p=$ 0,8107), с нормальной геометрией ЛЖ - с $19 \%$ до $16 \%$ ( $p=0,7570)$. Количество больных ГБ с сопутствующим СГ с признаками концентрического ремоделирования ЛЖ осталось неизменным: до лечения $-6 \%$, после - $6 \%$. Влияние статинотерапии на сосудистое ремоделирование у больных ГБ с СГ характеризовалось тенденцией к уменьшению толщины интима-медиального комплекса правой $(0,769 \pm 0,276$ мм против $0,701 \pm 0,222$ мм, $p=0,512)$ и левой $(0,759 \pm 0,185$ мм против 0,745 $\pm 0,179$ мм, $p=0,978)$ общих сонных артерий.

Выводы. У больных ГБ с сопутствующим СГ антигипертензивная терапия в течение года препаратами первой линии с добавлением статинов ассоциируется с достижением целевого уровня САД в активный период суток у $74 \%$, в пассивный период - у 65 \% пациентов (по данным СМАД), однако не сопровождалась достоверным уменьшением полостей, толщины стенок, массы миокарда ЛЖ, улучшением его диастолического наполнения, уменьшением толщины интима-медиального комплекса.

Arterial hypertension $(\mathrm{AH})$ is one of the most common chronic diseases. Its combination with other basic cardiovascular risk factors (age, high pulse pressure in elderly, smoking, dyslipidemia, increased levels of fasting glucose and impaired glucose tolerance, abdominal obesity and cardiovascular diseases in family anamnesis) significantly increases risks of fatal and non-fatal cardiovascular events [1]. Among additional unfavorable factors, hypothyroidism syndrome with its subclinical forms in particular deserves special attention. Subclinical hypothyroidism $\mathrm{SH}$ ) is the most common condition in thyroid pathology, which in the vast majority of cases is associated with autoimmune thyroiditis [2-7]. There is a proven connection between the manifest hypothyroidism and appearance of the pronounced changes in the structure and function of the heart, as well as with the progression of atherosclerosis and diseases related to it [8]. With the development of modern diagnostic methods, more and more data are 
accumulating regarding the negative effect of subclinical hypothyroidism on the cardiovascular system [9-19], albeit it is less pronounced than in other factors of cardiovascular risk [20-32].

Positive effect of the replacement therapy in various forms of the hypothyroidism has been proved, subclinical in particular. At the same time, there is a lack of information regarding the influence of statins on the indices of the structure and function of the heart and blood vessels due to their pleiotropic effects in patients with arterial hypertension combined with $\mathrm{SH}$. The widespread use of statins in patients with arterial hypertension and various comorbid conditions dictates the necessity of the study of their effects in patients with $\mathrm{AH}$ combined with $\mathrm{SH}$, and the study direction is, certainly, an issue of the current interest in modern internal medicine.

\section{Aim}

To study the effect of a long-term statin therapy on the cardiac structure and function, as well as on vascular remodeling in patients with arterial hypertension combined with subclinical hypothyroidism.

\section{Material and methods}

The studies were conducted at the clinical base of the Department of Propedeutics of Internal Medicine, Radiation Diagnostics and Radiation Therapy of ZSMU in the cardiology department of the CNI "City Hospital No. 6" of the Zaporizhzhia City Council.

After signing an informed consent, 31 patients (mean age $58 \pm 10$ years, $90 \%$ women) with $\mathrm{AH}$ grade $1-3$, stage II, of high and very high additional cardiovascular risks with the concomitant subclinical hypothyroidism were enrolled in the study. The diagnosis of $\mathrm{AH}$ was established in accordance with the recommendations of the Association of Cardiologists of Ukraine [1], and the diagnosis of subclinical hypothyroidism in accordance with the recommendations of the European Thyroid Association [33].

All patients received a combination of two or three first-line antihypertensive drugs at average therapeutic daily doses, and atorvastatin at a dose of 20-30 mg per day. Prior to treatment and after more than a year of follow-up, all patients underwent an echocardiographic examination and a carotid artery scan using My Lab Seven (Italy) device to study changes in the structural, geometric, and functional parameters of the heart and blood vessels. $24 \mathrm{~h}$-monitoring of blood pressure was performed before the initiation of therapy as well as a year later on a bifunctional device "Cardiotechnics-04" ("Incart", St. Petersburg, RF) with the simultaneous registration of blood pressure and ECG.

Statistical processing of the material was carried out using the software package Statistica 13.0 (StatSoft, USA), license number JPZ8041382130ARCN10-J. The normality of distribution of the quantitative signs was analyzed using the Shapiro-Wilk test. Parameters that had normal distribution are presented in the form of arithmetic mean and standard deviation $(M \pm S D)$.

For the indices that had a distribution that was different from normal, descriptive statistics data were provided in the form of median and lower and upper quartile -
Me (Q25; Q75). Comparisons of the quantitative indices across the groups were carried out using the Student's and Mann-Whitney criteria, depending on the character of distribution. Qualitative indices were compared using Pearson's $X^{2}$. A difference of $P<0.05$ was considered statistically significant. All tests were two-sided.

\section{Results}

Under the influence of antihypertensive therapy with addition of atorvastatin, $74 \%(23 / 31)$ of patients reached the target level of the systolic blood pressure during the daytime observation period, $65 \%(20 / 31)$ of patients - during the nighttime observation period; target diastolic blood pressure for the daytime observation period was reached in $87 \%$ (27/31) of patients, while for the nighttime observation period - in $71 \%$ (22/31) of patients.

However, under the influence of therapy, there was no significant change in the size of the cavities of the left atrium and both ventricles. The size of the left atrium before the treatment was $4.13 \pm 0.48 \mathrm{~cm}$, after $4.30 \pm 0.78 \mathrm{~cm}(P=0.617)$. The end-diastolic size of the left ventricle before treatment was $5.10 \pm 0.60 \mathrm{~cm}$, after a year of therapy $5.04 \pm 0.57 \mathrm{~cm},(P=0.751)$. The end-systolic size of the left ventricle before treatment was $3.11 \pm 0.38 \mathrm{~cm}$, and after $3.06 \pm 0.45 \mathrm{~cm}$ $(P=0.720)$. The diastolic size of the right ventricle before the treatment was $1.85 \pm 0.60 \mathrm{~cm}$, after a year of follow-up $2.01 \pm 0.47 \mathrm{~cm}$, the changes were statistically insignificant $(P=0.281)$.

The absence of changes in the end diastolic and systolic sizes of the left ventricular cavity, as expected, didn't lead to statistically significant $(P=0.262$ ) changes in its ejection fraction at the end of the annual follow-up period (before treatment $68.84 \pm 5.43 \%$, after $67.13 \pm 5.45 \%$ ).

No significant changes in thicknesses of the interventricular septum and the posterior wall of the left ventricle were observed. Before the beginning of treatment IVSd was $1.00 \pm 0.19 \mathrm{~cm}$, after it became $1.04 \pm 0.20 \mathrm{~cm}$, the difference is insignificant $(P=0.460)$. LVPWd before the treatment was $1.04 \pm 0.19 \mathrm{~cm}$, after $1.02 \pm 0.70 \mathrm{~cm}$, the difference is also insignificant $(P=0.632)$.

Due to the absence of the significant changes in the sizes of the left ventricular cavity and its walls, there were no significant changes in the relative thickness of the wall (before treatment $0.41 \pm 0.07$, after $0.41 \pm 0.07$, $P=0.871)$, as well as in the left ventricular mass index (before treatment $122.29 \pm 37.36 \mathrm{~g} / \mathrm{m}^{2}$, after $118.00 \pm 31.00 \mathrm{~g} / \mathrm{m}^{2}, \mathrm{P}=0.849$ ).

The specific gravity of patients with eccentric left ventricular hypertrophy after a year of treatment increased from $32 \%(n=10)$ to $39 \%(n=12)(P=0.5668)$, with concentric hypertrophy decreased from $42 \%$ $(n=13)$ to $39 \%(n=12)(P=0.8107)$, with normal left ventricular geometry went from $19 \%(n=6)$ to $16 \%$ $(n=15)(P=0.7570)$, however, none of the changes reached the statistical probability limit. The number of patients with $\mathrm{AH}$ with the concomitant subclinical hypothyroidism with signs of concentric left ventricular remodeling remained unchanged $-6 \%(n=2)$ before treatment, $6 \%(n=2)$ after. 
Analysis of the left ventricular diastolic function indices revealed no significant effect of the antihypertensive therapy with statin supplementation in patients with $\mathrm{AH}$ and a concomitant subclinical hypothyroidism on the end-diastolic pressure level; (E/e' before treatment $7.98 \pm 2.7$, after treatment $8.04 \pm 2.46$; $P=0.871$ ), on the ratio of the early left ventricular filling velocity to the velocity of atrial systole (E/A before treatment $0.86 \pm 0.32$, after treatment $0.81 \pm 0.28$; $\mathrm{P}=0.545)$, on the mean pulmonary artery pressure (before treatment $16.29 \pm 5.08 \mathrm{~mm} \mathrm{Hg}$, after treatment $15.81 \pm 4.98 \mathrm{~mm} \mathrm{Hg}, \mathrm{P}=0.686$ ).

The study of left ventricular diastolic filling types in dynamics revealed a tendency towards a decrease in the specific gravity of patients with "normal" type of filling of the left ventricle from $10 \%(n=3)$ to $6 \%$ ( $n=2)(P=0.5638)$, with "pseudonormal" filling from $19 \%(n=6)$ to $16 \%(n=5)(P=0.7570)$, and to an increase of the percentage of patients with the left ventricular filling type "impaired relaxation" from $71 \%$ $(n=22)$ to $77 \%(n=24),(P=0.5922)$. No patients with a restrictive left ventricular filling type were registered.

Transvalvular peak pressure gradients also did not change significantly under the influence of treatment: transmitral $(P=0.587)$, transaortic $(P=0.563)$, transtricuspid $(P=0.509)$, transpulmonary $(P=0.256)$.

The influence of the statin therapy on vascular remodeling in patients of this group was characterized by a tendency towards a decrease in thickness of the intima-media complex of the right $(0.769 \pm$ $0.276 \mathrm{~mm}$ vs. $0.701 \pm 0.222 \mathrm{~mm}, \mathrm{p}=0.512$ ) and left $(0.759 \pm 0.185 \mathrm{~mm}$ vs. $0.745 \pm 0.179 \mathrm{~mm}, \mathrm{P}=0.978)$ common carotid arteries.

\section{Discussion}

Data of literature sources and the results of our own studies regarding the dependence of indices of the heart structure and function in patients with arterial hypertension on the negative impact of subclinical hypothyroidism were described by us in the previous works [34], including the analysis of the effect of statins on the indices of 24h-blood pressure monitoring and their changes after a long-term intake by patients of this category $[35,36]$.

In the study [37], researchers analyzed the effect of $\mathrm{SH}$ on the diastolic function of the left ventricle by studying changes in time intervals with the help of a pulsed-wave Doppler. A similar analysis is complemented by the data of pulsed-wave tissue Doppler imaging in the publication [38]. Analyzing the modifying effect of hypothyroidism on cardiovascular pathology, the authors of the last publication point to the important changes in the structure and function of the heart, particularly in the diastolic function, in patients with hypothyroidism, the severity of which depends, according to the researchers, on the severity and duration of the thyroid hormone deficit. Similar results were also obtained with the help of modern diagnostic methods - magnetic resonance imaging and radionuclide ventriculography [39], which coincide with the data obtained by us.

However, there is a lack of information regarding the influence of statin therapy on the heart and blood vessels in patients with arterial hypertension combined with $\mathrm{SH}$. The results of our studies strongly suggest that the presence of a concomitant subclinical hypothyroidism in patients with $\mathrm{AH}$ significantly affects structural and geometric remodeling of the heart and blood vessels, which, along with the disorders of lipid metabolism, are a basis for prescription of statins to the patients in this category. In patients with $\mathrm{AH}$ and a concomitant $\mathrm{SH}$, there was an inhibition of the processes of reverse pathological remodeling of the left ventricle observed on the background of antihypertensive therapy, even provided the addition of statins to the therapeutic regimens.

Achievement of the target level of blood pressure according to $24 \mathrm{~h}-\mathrm{BPM}$ in $75 \%$ of patients with $\mathrm{AH}$ with subclinical hypothyroidism on the background of antihypertensive therapy with the addition of statins was not accompanied by a significant reduction in the cavity size, wall thicknesses, LV mass, improvement of the diastolic filling and systolic function, decrease in the thickness of intima-media complex [36,37]. The data obtained allow us to consider a concomitant subclinical hypothyroidism in patients with $\mathrm{AH}$ as a negative factor of additional cardiovascular risk, which should be taken into a consideration when prescribing therapy.

\section{Conclusions}

1. In patients with $\mathrm{AH}$ with a concomitant subclinical hypothyroidism, the antihypertensive therapy carried out during the year using first-line drugs with addition of atorvastatin is accompanied by an achievement of target level of SBP in the active period of the day in $75 \%$, in the passive period - in $65 \%$ of patients (according to the 24h-BPM data).

2. Achievement of the target level of blood pressure in patients with $\mathrm{AH}$ with subclinical hypothyroidism on the background of antihypertensive therapy with addition of statins was not accompanied by a significant reduction in cavity sizes, wall thicknesses, LV mass, improvement in LV diastolic filling, and decrease in the thickness of intima-media complex.

Prospects for further studies are to investigate the effect of statin therapy as well as hormone replacement therapy on the structural-geometric and functional parameters of the heart and blood vessels in patients with $\mathrm{AH}$ with a concomitant subclinical hypothyroidism.

Conflicts of interest: authors have no conflict of interest to declare. Конфиікт інтересів: віАсутній.

Надійшла Ао реАакції / Received: 12.10.2020

Після Аоопрацювання / Revised: 10.11.2020

Прийнято Ао Аруку / Accepted: 18.11.2020

Information about authors:

Novikov Ye. V., PhD-student of the Department of Propedeutics of Internal Medicine, Radiation Diagnostics and Radiation Therapy, Zaporizhzhia State Medical University, Ukraine.

Potapenko M. S., MD, PhD, Associate Professor of the Department of Anesthesiology and Intensive Care, Zaporizhzhia State Medical University, Ukraine. 


\section{Відомості про авторів:}

Новіков $€$. B., PhD-аспірант каф. пропедевтики внутрішньої медицини, променевої діагностики і променевої терапії, Запорізький державний медичний університет, Україна.

Потапенко М. С., канА. меА. наук, Аоцент каф. анестезіології та інтенсивної терапії, Запорізький Аержавний медичний університет, Україна.

\section{Сведения об авторах:}

Новиков Е. B., PhD-аспирант каф. пропедевтики внутренней меАицины, лучевой Аиагностики и мучевой терапии, Запорожский государственный медицинский университет, Украина.

Потапенко М. С., канА. меА. наук, Аоцент каф. анестезиологии и интенсивной терапии, Запорожский государственный медицинский университет, Украина.

\section{References}

[1] Working group on arterial hypertension of Ukranian association of cardiologists. (2012). Onovlena ta adaptovana klinichna nastanova, zasnovana na dokazakh 2012: praktychni rekomendatsii [Updated and adapted clinical guidance, based on the evidence of 2012: Practical recommendations]. Arteryalnaia hypertenzyia, (1), 96-152. [in Ukranian].

[2] Vernigorodsky, V. S., Fetisova, N. M., \& Vernigorodskaya, M. V. (2013). Provospalitelnye tsitokiny i ikh rol v razvitii serdechno-sosudistykh oslozhnenii u bolnykh gipotireozom [Proinflammatory cytokines and their role in the development of cardiovascular complications in patients with hypothyroidism]. Rossiiskii mediko-biologicheskii vestnik imeni akademika I. P. Pavlova, 21(2), 93-96. [in Russian]. http://dx.doi. org/10.17816/PAVLOVJ2013293-96

[3] Nekrasova, T. A., Ledentsova, O. V., Strongin, L. G., Kazakova, L. V., \& Lukushkina, A. Yu. (2011). Osobennosti gemodinamiki u bolnykh s autoimmunnym tireoiditom i subklinicheskim gipotireozom $v$ raznykh vozrastnykh gruppakh [Specific features of hemodynamics in the patients of different age groups presenting with autoimmune thyroiditis and subclinical hypothyroidism]. Problemy endokrinologii, 57(3), 21-24. [in Russian]. https://doi.org/10.14341/probl201157321-24

[4] Petunina, H. A., \& Trukhina, L. V. (2013). Gipotireoz [Hypothyroidism]. Russkii Meditsinskii Zhurnal, 21(12), 664-666. [in Russian]

[5] Kononenko, A. H., \& Kravchenko, V. M. (2016). Zminy pokaznykiv obminu rechovyn pry eksperymentalnomu hipotyreozi [Changes in indicators in the exchange of speech in case of experimental hypothyroidism]. Mizhnarodnyi endokrynolohichnyi zhurnal, (2), 174. [in Ukrainian]

[6] Kadzharyan, V. G., Melnik, A. I., Bidzilya, P. P., \& Solovyuk, S. A. (2014). Otsenka sostoyaniya lipidnogo obmena pri disfunktsii shchitovidnoi zhelezy [Assessment of the state of lipid exchange in thyroid dysfunction]. Zaporozhye medical journal, (1), 20-22. [in Russian]. https://doi. org/10.14739/2310-1210.2014.1.23657

[7] Horodynska, O. Yu., \& Bobyriova, L. Ye. (2016). Prohnostychna kharakterystyka poshyrennia hipotyreozu v Poltavskii oblasti ta $v$ Ukraini v tsilomu za umov yodnoho defitsytu [Prognostic characteristics of hypothyroidism prevalence in the Poltava region and in Ukraine]. Mizhnarodnyi endokrynolohichnyi zhurnal, (2), 44-49. [in Ukrainian].

[8] Cappola, A. R., \& Ladenson, P. W. (2003). Hypothyroidism and atherosclerosis. The Journal of clinical endocrinology and metabolism, 88(6), 2438-2444. https://doi.org/10.1210/jc.2003-030398

[9] Monzani, F., Caraccio, N., Kozàkowà, M., Dardano, A., Vittone, F., Virdis, A., Taddei, S., Palombo, C., \& Ferrannini, E. (2004). Effect of levothyroxine replacement on lipid profile and intima-media thickness in subclinical hypothyroidism: a double-blind, placebo- controlled study. The Journal of clinical endocrinology and metabolism, 89(5), 2099-2106. https://doi.org/10.1210/jc.2003-031669

[10] Biondi, B., \& Klein, I. (2004). Hypothyroidism as a risk factor for cardiovascular disease. Endocrine, 24(1), 1-13. https://doi.org/10.1385/ ENDO:24:1:001

[11] Hak, A. E., Pols, H. A., Visser, T. J., Drexhage, H. A., Hofman, A., \& Witteman, J. C. (2000). Subclinical hypothyroidism is an independent risk factor for atherosclerosis and myocardial infarction in elderly women: the Rotterdam Study. Annals of internal medicine, 132(4), 270-278. https://doi.org/10.7326/0003-4819-132-4-200002150-00004

[12] Lioudaki, E. Mavroeidi, N. G., Mikhailidis, D. P. \& Ganotakis, E. S. (2013). Subclinical hypothyroidism and vascular risk: an update. Hormones (Athens, Greece), 12(4), 495-506. https://doi.org/10.14310/ horm.2002.1437

[13] Rodondi, N., den Elzen, W. P., Bauer, D. C., Cappola, A. R., Razvi, S., Walsh, J. P., ... Thyroid Studies Collaboration (2010). Subclinical hypothyroidism and the risk of coronary heart disease and mortality. JAMA, 304(12), 1365-1374. https://doi.org/10.1001/jama.2010.1361
[14] Walsh, J. P., Bremner, A. P., Bulsara, M. K., O'Leary, P., Leedman, P. J., Feddema, P., \& Michelangeli, V. (2005). Subclinical thyroid dysfunction as a risk factor for cardiovascular disease. Archives of internal medicine, 165(21), 2467-2472. https://doi.org/10.1001/archinte.165.21.2467

[15] Karmisholt, J., Andersen, S., \& Laurberg, P. (2010). Analytical goals for thyroid function tests when monitoring patients with untreated subclinical hypothyroidism. Scandinavian journal of clinical and laboratory investigation, 70(4), 264-268. https://doi.org/10.3109/00365511003782778

[16] Andersen, M. N., Olsen, A. S., Madsen, J. C., Kristensen, S. L., Faber, J., Torp-Pedersen, C., Gislason, G. H., \& Selmer, C. (2016). Long-Term Outcome in Levothyroxine Treated Patients With Subclinical Hypothyroidism and Concomitant Heart Disease. The Journal of clinical endocrinology and metabolism, 101(11), 4170-4177. https:// doi.org/10.1210/jc.2016-2226

[17] Biondi B. (2012). Natural history, diagnosis and management of subclinical thyroid dysfunction. Best practice \& research. Clinical endocrinology \& metabolism, 26(4), 431-446. https://doi.org/10.1016/j. beem.2011.12.004

[18] Danzi, S., \& Klein, I. (2014). Thyroid disease and the cardiovascular system. Endocrinology and metabolism clinics of North America, 43(2), 517-528. https://doi.org/10.1016/j.ecl.2014.02.005

[19] Faber, J., \& Selmer, C. (2014). Cardiovascular disease and thyroid function. Frontiers of hormone research, 43, 45-56. https://doi. org/10.1159/000360558

[20] Cabral, M. D., Teixeira, P. F., Silva, N. A., Morais, F. F., Soares, D. V., Salles, E., Henriques, J. M., Leite, S. P., Montenegro, C. A., \& Vaisman, M. (2009). Normal flow-mediated vasodilatation of the brachial artery and carotid artery intima-media thickness in subclinical hypothyroidism. Brazilian journal of medical and biological research, 42(5), 426-432. https://doi.org/10.1590/s0100-879x2009000500005

[21] Chiche, F., Jublanc, C., Coudert, M., Carreau, V., Kahn, J. F., \& Bruckert, E. (2009). Hypothyroidism is not associated with increased carotid atherosclerosis when cardiovascular risk factors are accounted for in hyperlipidemic patients. Atherosclerosis, 203(1), 269-276. https://doi. org/10.1016/j.atherosclerosis.2008.06.011

[22] Takashima, N., Niwa, Y., Mannami, T., Tomoike, H., \& Iwai, N. (2007). Characterization of subclinical thyroid dysfunction from cardiovascular and metabolic viewpoints: the Suita study. Circulation journal, 71(2), 191-195. https://doi.org/10.1253/circj.71.191

[23] Vierhapper, H., Nardi, A., Grösser, P., Raber, W., \& Gessl, A. (2000) Low-density lipoprotein cholesterol in subclinical hypothyroidism. Thyroid, 10(11), 981-984. https://doi.org/10.1089/thy.2000.10.981

[24] Altshuler, N. E., Petunina, N. A., Nikolayev, A. P., \& Chernyshova, T. V. (2011). Sravnitelnyi analiz kontsentratsii gormonov zhirovoi tkani, pokazatelei lipidnogo obmena i insulinorezistentnosti pri subklinicheskom gipotireoze v zavisimosti ot nalichiya/otsutstviya zamestitelnoi terapi levotiroksinom [A comparative analysis of the lipid tissue hormones concentration, lipid metabolism and insulin resistance in subclinical hypothyroidism depending on the presence/absence of the levothyroxin replacement therapy]. Clinical and experimental thyroidology, 7(3), 53-58. [in Russian]. https://doi.org/10.14341/ket20117353-58

[25] Nekrasova, T. A., Shcherbatyuk, T. G., Davydenko, D. V., Ledentsova, O. V., \& Strongin, L. G. (2011). Osobennosti perekisnogo okisleniya lipidov i belkov pri autoimmunnom tireoidite bez is minimalnoi tireoidnoi disfunktsiei [Peculiarities of lipid and protein peroxidation in autoimmune thyroiditis with and without mild thyroid dysfunction]. Klinicheskaya $i$ eksperimentalnaya tireoidologiya, (4), 38-43. [in Russian].

[26] Allport, J., McCahon, D., Hobbs, F. D., \& Roberts, L. M. (2013). Why are GPs treating subclinical hypothyroidism? Case note review and GP survey. Primary health care research \& development, 14(2), 175-184. https://doi.org/10.1017/S1463423612000230

[27] Brenta, G., Vaisman, M., Sgarbi, J. A., Bergoglio, L. M., Andrada, N. C., Bravo, P. P., Orlandi, A. M., Graf, H., \& Task Force on Hypothyroidism of the Latin American Thyroid Society (LATS) (2013). Clinical practice guidelines for the management of hypothyroidism. Arquivos brasileiros de endocrinologia e metabologia, 57(4), 265-291. https://doi. org/10.1590/s0004-27302013000400003

[28] Cooper, D. S. \& Biondi, B. (2012). Subclinical thyroid disease. Lancet, 379(9821), 1142-1154. https://doi.org/10.1016/S0140-6736(11)60276-6

[29] Duntas, L. H., \& Wartofsky, L. (2007). Cardiovascular risk and subclinical hypothyroidism: focus on lipids and new emerging risk factors. What is the evidence?. Thyroid, 17(11), 1075-1084. https://doi.org/10.1089/ thy.2007.0116

[30] Sviridonova, M. A Fadeyev, V V Sych, Y P. \& Melnichenko, G. A (2013). Clinical significance of TSH circadian variability in patients with hypothyroidism. Endocrine research, 38(1), 24-31. https://doi.org/10.3 109/07435800.2012.710696

[31] Virgini, V., Collet, T. H., Christ, E., Aujesky, D., \& Rodondi, N. (2012). Faut-il dépister et traiter l'hypothyroïdie infraclinique? [Should we screen and treat subclinical hypothyroidism?]. Revue medicale suisse, 8(331), 501-506. 
[32] Weiss, I. A., Bloomgarden, N., \& Frishman, W. H. (2011). Subclinical hypothyroidism and cardiovascular risk: recommendations for treatment. Cardiology in review, 19(6), 291-299. https://doi.org/10.1097/ CRD.0b013e318227df87

[33] Pearce, S. H., Brabant, G., Duntas, L. H., Monzani, F., Peeters, R. P., Razvi, S., \& Wemeau, J. L. (2013). 2013 ETA Guideline: Management of Subclinical Hypothyroidism. European thyroid journal, 2(4), 215-228. https://doi.org/10.1159/000356507

[34] Syvolap, V. V., \& Novikov, Ye. V. (2019). Osoblyvosti kardiovaskuliarnoho remodeliuvannia u khvorykh na hipertonichnu khvorobu vysokoho dodatkovoho ryzyku z suputnim subklinichnym hipotyreozom [Peculiarities of cardiovascular remodeling in hypertensive patients at high additional risk with concomitant subclinical hypothyroidism]. Zaporozhye medical journal, 21(1), 13-20. [in Ukranian]. https://doi. org/10.14739/2310-1210.2019.1.155792

[35] Syvolap, V. V., Novikov, Ye. V., \& Potapenko, M. S. (2019). Vplyv subklinichnoho hipotyreozu na pokaznyky dobovoho monitoruvannia arterialnoho tysku u khvorykh na hipertonichnu khvorobu vysokoho dodatkovoho ryzyku [Influence of subclinical hypothyroidism on indicators of 24-hour arterial blood pressure monitoring in hypertensive patients with high additional risk]. Zaporozhye medical journal, 21(2), 170-176. [in Ukranian]. https://doi.org/10.14739/2310-1210.2019.2.161329

[36] Syvolap, V. V., Novikov, Ye. V., \& Potapenko, M. S. (2020). Vplyv statynoterapii na pokaznyky dobovoho monitoruvannia arterialnoho tysku u khvorykh na hipertonichnu khvorobu, shcho poiednana z subklinichnym hipotyreozom [Influence of statin therapy on 24-hour blood pressure monitoring indices in patients with arterial hypertension combined with subclinical hypothyroidism]. Zaporozhye medical journal, 22(1), 11-18. [in Ukranian]. https://doi.org/10.14739/2310-1210.2020.1.194470

[37] Biondi, B., Fazio, S., Palmieri, E. A., Carella, C., Panza, N., Cittadini, A. Bonè, F., Lombardi, G., \& Saccà, L. (1999). Left ventricular diastolic dysfunction in patients with subclinical hypothyroidism. The Journal of clinical endocrinology and metabolism, 84(6), 2064-2067. https://doi. org/10.1210/jcem.84.6.5733

[38] Vitale, G., Galderisi, M., Lupoli, G. A., Celentano, A., Pietropaolo, I., Parenti, N., De Divitiis, O., \& Lupoli, G. (2002). Left ventricular myocardial impairment in subclinical hypothyroidism assessed by a new ultrasound tool: pulsed tissue Doppler. The Journal of clinical endocrinology and metabolism, 87(9), 4350-4355. https://doi.org/10.1210/ jc.2002-011764

[39] Biondi B. (2020). Heart in Overt and Subclinical Hypothyroidism. In G. Iervasi, A. Pingitore, A. Gerdes, S. Razvi (Eds.), Thyroid and Heart (pp. 229-237). Springer. https://doi.org/10.1007/978-3-030-36871-5_17 